American Journal of Environmental Sciences 5 (3): 209-217, 2009

ISSN 1553-345X

(C) 2009 Science Publications

\title{
Toxicity Testing and the Effect of Landfill Leachate in Malaysia on Behavior of Common Carp (Cyprinus carpio L., 1758; Pisces, Cyprinidae)
}

\author{
${ }^{1}$ Jaffar Y.M. Alkassasbeh, ${ }^{2}$ Lee Yook Heng and ${ }^{1}$ Salmijah Surif \\ ${ }^{1}$ School of Environmental and Natural Resource Sciences, \\ ${ }^{2}$ School of Chemical Sciences and Food Technology, \\ Faculty of Science and Technology, University Kebangsaan Malaysia, \\ 43600 UKM Bangi, Selangor, Malaysia
}

\begin{abstract}
Problem Statement: Landfill leachate had been implicated in environmental pollution, developmental anomalies, birth defect and surface and groundwater pollution worldwide. This study has been conducted to determine the toxicity of landfill leachate from three different landfills in Malaysia on fry common carp (Cyprinus carpio L., 1758; Pisces, Cyprinidae) in combination with some physico-chemical parameters analysis. Approach: Leachates were collected from Air Hitam (AHL), Ampar Tenang (ATL) and Sungai Sedu (SSL) landfills. The experiments were performed as three replicates using a total of 180 carps for each definitive test. The semi-static renewal method of acute toxicity test was used. The data obtained were statically evaluated by the use of the EPA computer program based on Finney's Probit Analysis Method. Results: The leachate used in this study had an invariable of (1640-7600 $\left.\mathrm{mg} \mathrm{L}^{-1}\right)$ COD and (321.22-956.86 $\left.\mathrm{mg} \mathrm{L}^{-1}\right)$ Ammonical-N. The $96 \mathrm{~h}$ $\mathrm{LC}_{50}$ values of landfills leachate from the three landfills using fry $C$. carpio individuals with an average weight of $0.92 \pm 0.24 \mathrm{~g}$ and average length of $3.83 \pm 0.19 \mathrm{~cm}$ were found to be 1.132, 2.0 and $3.822 \%$ respectively. Among the behavioral changes observed for the individual fish at different leachate concentrations, decline in general activity, loss of balance, breathing difficulties, excessive mucosal secretion and gathering at the surface for breathing. Conclusion: This study of acute toxicity to the recommended fish species, C. caprio, is considered the first in Malaysia. Further research with toxicity testing methods directly on fish will be very useful in assessing possible ecological risk assessment of landfill leachate.
\end{abstract}

Key words: Landfill leachate, acute toxicity test, $\mathrm{LC}_{50}$, common carp, behavioral changes

\section{INTRODUCTION}

Landfill is considered one of the most widely practiced methods for the disposal of Municipal Solid Waste (MSW) since up to $95 \%$ total MSW collected worldwide is disposed of in landfills ${ }^{[1]}$. Leachate the potentially polluting liquor which accumulates beneath a landfill site resulting from the infiltration and percolation of rainfall, groundwater, runoff, or flood water into and through an existing or abandoned solid waste landfill site. Leachate contains substantial amounts of dissolved organics (BOD and COD), Xenobiotic Organic Compound (XOCs), inorganic salts, ammonia, heavy metals and other toxicants ${ }^{[2-3]}$. More than 200 organic compounds have been identified in municipal landfill leachate ${ }^{[4-5]}$, with upwards of 35 compounds having the potential to cause harm to the environment and human health ${ }^{[4]}$. High level of ammonia is toxic to many living organisms in surface water and contributes to eutrophication, dissolved oxygen depletion ${ }^{[6]}$.

A great number of uncontrolled landfills without appropriate bottom liners and leachate collection systems have been wide spread in Malaysia, there are about 230 landfills with different sizes and ages recognized officially and an estimated three times more illegal dumps. Most of the landfills are not come under the sanitary landfill classification because there are no facilities to collect and/or treat the leachate and there is no infrastructure to exploit the landfill gas. There are only few sanitary landfills with leachate treatment and gas exploitation facilities ${ }^{[7]}$.

Acute toxicity tests provide information on the time and/or concentration causing a significant effect or detectable response in $50 \%$ of the exposed population of test organisms. The tests are considered ecologically

Corresponding Author: Jaffar Y.M. Alkassasbeh, School of Environmental and Natural Resource Sciences, University Kebangsaan Malaysia, 46300 Bangi, Selangor, Malaysia, email: abokassab@yahoo.com. 
significant and legally defensible, simple and cost effective $^{[8]}$. Acute toxicity studies can provide fast and valuable information and indicate whether further toxicity studies should be conducted. Toxicity tests have traditionally been performed with a variety of freshwater and saltwater species representing algae, fish and invertebrates. Although the initial aquatic toxicity tests were carried out using bacteria, invertebrates and other groups, they can in no way replace the actual test performed on fish, which is the last chain in the aquatic food cycle ${ }^{[9]}$.

There are a number of studies carried out to estimate the toxicity of landfill leachate using fish as test organism. Stephen and $\mathrm{Nail}^{[10]}$ monitored the mortality of fathead minnows fish exposed to filtered and unfiltered leachates. Different concentrations of leachates were used to test the survival of tilapia (Sarotherodon mossambicus) $^{[11]}$. Sisinno et al. ${ }^{[12]}$ evaluated toxicity of municipal dump leachate using zebrafish (Brachydanio rerio). Osaki et al. ${ }^{[13]}$ determined the toxic potency of the landfill leachates to the larvae and adult of Japanese Medaka (Oryzias latipes). Although the toxicity of landfill leachate was studied for numerous fish species, the complete lack of landfill leachate toxicity data for common carp (Cyprinus carpio L.) fish, which have a widespread and presently cultured all over Asia, in most parts of Europe and on a small scale in some countries of Africa and Latin America, in addition to that, the limitation of landfill leachate toxicity studies for Malaysia landfills in the open literature, led us to carry out a study of landfill leachate toxicity using $C$. carpio fish as a test organism. The objectives of this study included toxicity evaluation of landfill leachate from three different landfills in Malaysia in combination with physicochemical analyses of leachate quality. The survival of the fish exposed to the test substance was compared with the survival of the fish in an appropriate control over a fixed period of time. Behavioral changes of the above mentioned species were observed for various leachate concentrations and photographed using digital camera.

\section{MATERIALS AND METHODS}

Sites characteristics: The three locations were Air Hitam Landfill (AHL), Sungai Sedu Landfill (SSL) and Ampar Tenang Landfill (ATL). AHL is categorized in level IV, since all the requirements for environmental quality assessment are fully complied, which include daily waste spreading, compaction and cover, gas extraction and treatment system, leachate collection and treatment plant and artificial lining system. ATL had been upgraded to level I, which requires road accessibility, designated tipping area, weekly waste spreading, compaction and cover; in contrast, there is no liner system, no gas control and neither leachate control nor treatment. SSL has been classified in levels II which include the facilities of perimeter berm, gas venting, frequent waste spreading and compaction and frequent waste cover, but lack of liner system, leachate control and treatment. Table 1 shows general conditions of the studied locations.

Leachate: Raw landfill leachates were sampled from the collection ponds in the three landfill sites using well sealed bottles under conditions with minimized exposure to oxygen. In the laboratory, leachate was filtered through glass microfiber filter $(0.47 \mathrm{~mm})$ and stored at $4^{\circ} \mathrm{C}$ in dark for one week use, all samples were then frozen at $-18^{\circ} \mathrm{C}$ until needed. Prior to testing, the leachates were thawed at room temperature for a period of $10 \mathrm{~h}$. The leachate was analyzed for $\mathrm{pH}$ (Analyzer 300 M, pH electrode), DO (YSI 55 dissolved oxygen meter), conductivity (Hanna HI 8819 conductivity meter), TDS (Hach Sension 5), alkalinity, BOD, COD and ammonical-nitrogen according to APHA standard methods ${ }^{[14]}$.

Test species: This study was carried out in the hydrobiology laboratories of School of Environmental and natural Resource Sciences, National University of Malaysia. C. carpio L., used in this study was obtained from a local breeder and transported immediately to the laboratory within $25 \mathrm{~min}$ in appropriately aerated plastic bags. In the laboratory, for each tested leachate, a total of 200 fish were kept in 100 liter glass aquaria (width of $50 \mathrm{~cm}$, depth of $40 \mathrm{~cm}$ and a length of $100 \mathrm{~cm})$ containing filtered tap water $(\mathrm{pH}$ 6.2-6.4, dissolved oxygen concentration 7.3-8.5 $\mathrm{mg} \mathrm{L}^{-1}$, Conductivity $64-68 \mu \mathrm{s}$ and ammonia $<0.5 \mathrm{mg} \mathrm{L}^{-1}$ ), the aquaria were equipped with a water-cycling device by which the water was continuously aerated 1 week before putting the fish inside it, to remove chlorine. Fish were acclimated for 14 days with continuous aerating and the water renewed every $24 \mathrm{~h}$.

\begin{tabular}{|c|c|c|c|}
\hline Landfills & AHL & ATL & SSL \\
\hline Landfill type & $\begin{array}{l}\text { Sanitary } \\
\text { Level IV }\end{array}$ & $\begin{array}{l}\text { Open dump } \\
\text { Level I }\end{array}$ & $\begin{array}{l}\text { Open dump } \\
\text { Level II }\end{array}$ \\
\hline $\begin{array}{l}\text { Period of } \\
\text { landfilling }\end{array}$ & $1995-2007$ & 1998-now & 1998-now \\
\hline $\begin{array}{l}\text { Daily average of } \\
\text { wastes disposed } \\
\text { (tonnage) }\end{array}$ & $1000-2000$ & 200 & 180 \\
\hline Waste type & $\begin{array}{l}\text { Household, } \\
\text { Commercial, } \\
\text { and Industrial }\end{array}$ & $\begin{array}{l}\text { Household, } \\
\text { Commercial, } \\
\text { and Industrial }\end{array}$ & $\begin{array}{l}\text { Household, } \\
\text { Commercial, } \\
\text { and Industrial }\end{array}$ \\
\hline
\end{tabular}


The fish were fed with commercial fish food Aquadene $^{\circledR}$ once daily. Feeding was terminated $48 \mathrm{~h}$ prior the initiating of the experiment to reduce metabolic wastes. The temperature was maintained at $25 \pm 1^{\circ} \mathrm{C}$ and the photoperiod was set at $12 \mathrm{~h}$ of light and $12 \mathrm{~h}$ of dark during the entire experiment. Care was taken in order to keep the mortality rate less than $5 \%$ in the last 5 days before the experiments was started. Fry common carp with mean total length $3.83 \pm 0.19 \mathrm{~cm}$ (The total length of the species was measured using a milimetric ruler on fish measurement plate) and wet body weight $0.92 \pm 0.24 \mathrm{~g}$ (was weighted in a balance with $0.1 \mathrm{~g}$ accuracy), were used for acute toxicity tests in this study.

Acute toxicity test: Acute toxicity test with $C$. carpio L. was performed according to the APHA ${ }^{[14]}, \mathrm{OECD}^{[15]}$ and $\mathrm{EPA}^{[16]}$ recommendations. Laboratory static tests were conducted to determine the median lethal concentration $\left(\mathrm{LC}_{50}\right)$. Groups of 10 fish of similar size were randomly sampled and transferred with the help of small hand net from the acclimation tank into a suitable test chambers (i.e. aquarium) of 20 L capacity avoiding any possibility of mechanical injury to the test fish. Each aquarium was stocked with fish with a ratio of 1.0 g $1.0 \mathrm{~L}^{-1}$ water. Based on previous range finding tests, fish were exposed to different leachate concentrations (0.1, 1.0, 1.6, 2.5 and 4.0\% for AHL), (1.0, 1.5, 2.2, 3.2 and $4.6 \%$ for ATL) and (1.0, 1.8, 3.2, 5.6 and 7.5\% for SSL) prepared by filtered tap water as dilution water. A control group was made of dilution water only with out addition of leachate, there was no observed mortality in the control group and the fish looked healthy throughout the experiments. A flexible silicone tube attached to a regulated air supply was inserted through the test chambers and remained in its place throughout the test period to supply a sufficient amount of dissolved oxygen, the amount of dissolved oxygen was observed to be not less than $5 \mathrm{mg} \mathrm{L}^{-1}$. Physiochemical parameters $(\mathrm{pH}$, Conductivity, Dissolved oxygen and Temperature) were measured daily in each aquarium throughout the experiment. The water temperature was maintained at $24 \pm 1^{\circ} \mathrm{C}$. The control and each treated group were replicated three times. All experiments were carried out for a period of $96 \mathrm{~h}$. No food was given to the fish during the experiments. Mortality and behavioral changes of the healthy fish and the fish exposed to various concentrations of leachate were photographed with digital camera each $6 \mathrm{~h}$ for the whole test period. During the experiment, dead fish were removed immediately because such mortality in static bioassays may deplete the DO, affecting tolerance limits $^{[17]}$. The $96 \mathrm{~h} \mathrm{LC}_{50}$ for carp and its $95 \%$ confidence limits were calculated using a program based on Finneys Probit Analysis Method ${ }^{[18]}$.

\section{RESULTS}

Values of physico-chemical parameters of landfill leachate from the three locations are shown in Table 2.

The estimated LC values and it is confidence limits that resulted from the landfill leachate acute toxicity testing on $C$. carpio are listed in Table 3-5. Based on Finneys Probit Analysis Method using EPA software program, the mean $\mathrm{LC}_{50}$ values of landfills leachate from the three landfills (AHL, ATL and SSL) using C. carpio individuals with an average weight of $0.92 \pm 0.24 \mathrm{~g}$ and average length of $3.83 \pm 0.19 \mathrm{~cm}$ was found to be 1.132 , 2.0 and $3.822 \%$ respectively.

Table 2: Physico-chemical properties of landfill leachate samples $($ mean \pm SD)

\begin{tabular}{llll}
\hline Leachate & AHL & ATL & SSL \\
\hline Color & Black & Dark brown & Bright brown \\
Odor & Strong ammoniac & Mild ammoniac & Slightly ammoniac \\
pH & $7.36 \pm 0.01$ & $7.57 \pm 0.01$ & $7.9 \pm 0.01$ \\
Conductivity & $26.34 \pm 0.5$ & $14.72 \pm 0.26$ & $10.14 \pm 0.02$ \\
Dissolved oxygen & $0.78 \pm 0.03$ & $2.52 \pm 0.21$ & $1.13 \pm 0.04$ \\
BOD & $1228 \pm 1.73$ & $866 \pm 6.24$ & $507 \pm 6$ \\
COD & $7600 \pm 400$ & $3733.3 \pm 230.94$ & $1640 \pm 40$ \\
DOD/COD & 0.16 & 0.23 & 0.3 \\
Ammonical-N & $956.86 \pm 6.95$ & $470.5 \pm 9.5$ & $321.22 \pm 1.92$ \\
TDS & $9780 \pm 56.42$ & $7220.33 \pm 104.58$ & $6042 \pm 10.58$ \\
Alkalinity & $8300 \pm 20$ & $2860 \pm 26.46$ & $1580 \pm 17.32$ \\
\hline All
\end{tabular}

All units in $\mathrm{mg} \mathrm{L}^{-1}$ except electrical conductivity $\left(\mathrm{mS} \mathrm{cm}^{-1}\right), \mathrm{pH}$, odor, color (no unit)

Table 3: Estimated $96 \mathrm{~h} \mathrm{LC}$ values and confidence limits for AHL with carp fish

\begin{tabular}{lllr}
\multicolumn{3}{c}{ with carp fish } & \\
& & $95 \%$ confidence limits \\
Point & $\begin{array}{l}\text { Exposure } \\
\text { conc. }\end{array}$ & Lower & Upper \\
\hline LC 1.00 & 0.048 & 0.000 & 0.185 \\
LC 5.00 & 0.121 & 0.003 & 0.340 \\
LC 10.00 & 0.198 & 0.010 & 0.474 \\
LC 15.00 & 0.277 & 0.021 & 0.596 \\
LC 50.00 & 1.132 & 0.475 & 1.979 \\
LC 85.00 & 4.626 & 2.506 & 27.911 \\
LC 90.00 & 6.453 & 3.218 & 60.278 \\
LC 95.00 & 10.570 & 4.558 & 192.870 \\
LC 99.00 & 26.682 & 8.475 & 1764.910 \\
\hline
\end{tabular}

Table 4: Estimated 96 h LC values and confidence limits for ATL with carp fish

\begin{tabular}{|c|c|c|c|}
\hline \multirow[b]{2}{*}{ Point } & \multirow{2}{*}{$\begin{array}{l}\text { Exposure } \\
\text { conc. }\end{array}$} & \multicolumn{2}{|c|}{$95 \%$ confidence limits } \\
\hline & & Lower & Upper \\
\hline LC 1.00 & 0.643 & 0.229 & 0.966 \\
\hline LC 5.00 & 0.897 & 0.417 & 1.231 \\
\hline LC 10.00 & 1.071 & 0.572 & 1.407 \\
\hline LC 15.00 & 1.207 & 0.705 & 1.545 \\
\hline LC 50.00 & 2.001 & 1.569 & 2.504 \\
\hline LC 85.00 & 3.319 & 2.627 & 5.389 \\
\hline LC 90.00 & 3.740 & 2.893 & 6.629 \\
\hline LC 95.00 & 4.466 & 3.314 & 9.070 \\
\hline LC 99.00 & 6.228 & 4.229 & 16.512 \\
\hline
\end{tabular}


Am. J. Environ. Sci., 5 (3): 209-217, 2009

Table 5: Estimated $96 \mathrm{~h} \mathrm{LC}$ values and confidence limits for SSL with carp fish

\begin{tabular}{llll}
\hline & $\begin{array}{l}\text { Exposure } \\
\text { conc. }\end{array}$ & \multicolumn{2}{l}{ 95\% confidence limits } \\
Point & 1.271 & Lower & Upper \\
\hline LC 1.00 & 1.755 & 0.450 & 1.914 \\
LC 5.00 & 2.084 & 1.099 & 2.426 \\
LC 10.00 & 2.340 & 1.346 & 2.768 \\
LC 15.00 & 3.822 & 2.918 & 3.036 \\
LC 50.00 & 6.242 & 4.881 & 4.890 \\
LC 85.00 & 7.011 & 5.372 & 10.211 \\
LC 90.00 & 8.326 & 6.147 & 16.870 \\
LC 95.00 & 11.495 & 7.812 & 30.240 \\
LC 99.00 & & &
\end{tabular}

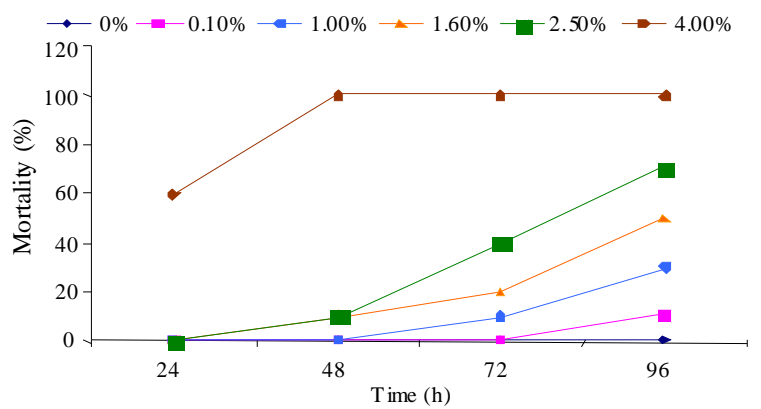

Fig. 1: Effect of AHL on carp fish

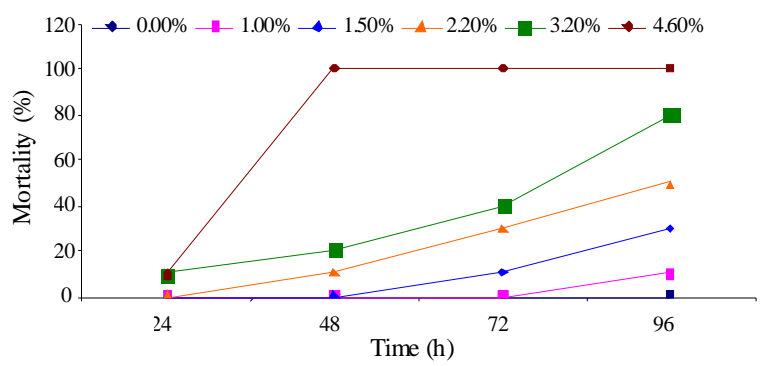

Fig. 2: Effect of ATL on carp fish

The 95\% confidence limits were (0.475-1.979\%), (1.569-2.504) and (2.918-4.890) respectively. The results show that landfill leachate is highly toxic to $C$. carpio. The effects of landfills leachate (AHL, ATL and SSL) on the Mortality of $C$. carpio with responding to time factor are shown in Fig. 1-3.

A significant mortality for carp fish was observed with the increment in concentration and exposure time for the three leachates. However, the lethal time correlated inversely with the concentration increment. AHL showed the highest toxicity with a total mortality concentration of $4.0 \%$ after $30 \mathrm{~h}$, followed by ATL with $4.6 \%$ after $42 \mathrm{~h}$ and lastly SSL with $7.5 \%$ after $78 \mathrm{~h}$.

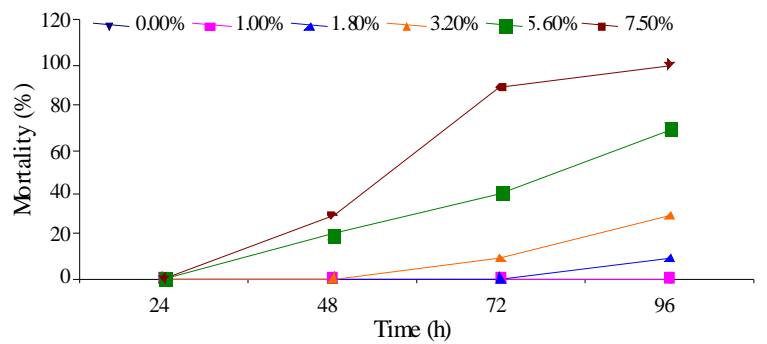

Fig. 3: Effect of SSL on Carp fish

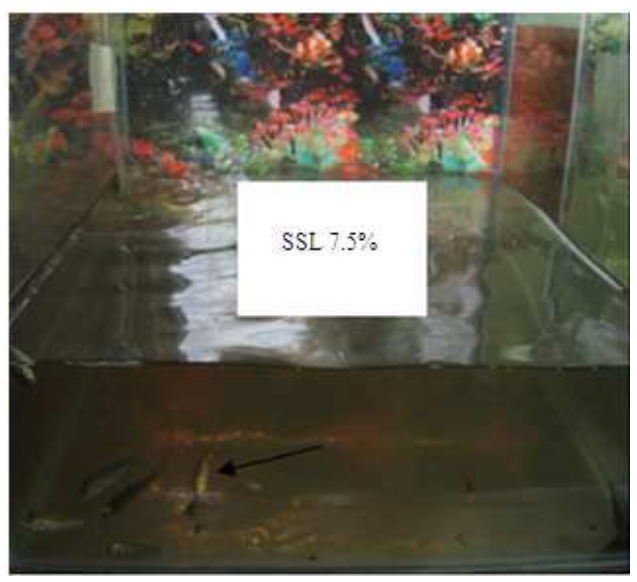

Fig. 4: The behavioural changes of carp fish Exposed to $7.5 \%$ of SSL

The change in behavioral pattern: In this study, $C$. carpio exposed to various concentrations of landfill leachate showed behavioral changes, observations of behavioral disorders were conducted at every $6 \mathrm{~h}$ for the whole period of test. All behavioral disorders in this study were photographed. Fig. 4-7.

There was no change in the behavior and the swimming patterns for the control group for the whole test period. The lowest concentrations $(0.1,1.0$ and $1.0 \%$ for AHL, ATL and SSL respectively) showed similar behavior with the control and the minimum rate of mortality was recorded, $0 \%$ for SSL and $10 \%$ for both ATL and AHL. Observed behavioral changes related to neurotoxin toxicity: loss of equilibrium, decline in general activity and tendency of fish to gather at water surface of the test cell started within the fish group exposed to $1.0,1.5$ and $1.8 \%$ concentrations (AHL, ATL and SSL respectively). On the other hand, sudden jerks, loss of balance, disorder in swimming patterns, breathing difficulties, excessive mucosal secretion in the gills and on the body surface, enlargement of eyes and gathering at the surface of test chambers for breathing were noticed gradually with leachate concentration increase during the tests. 


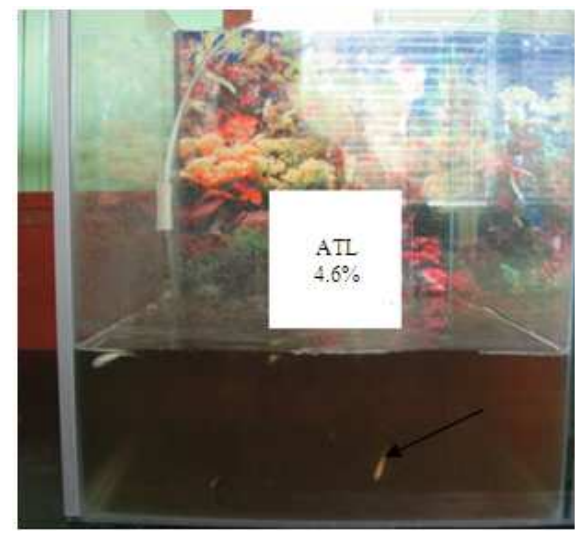

Fig. 5: The behavioural changes of carp fish Exposed to $4.6 \%$ of ATL

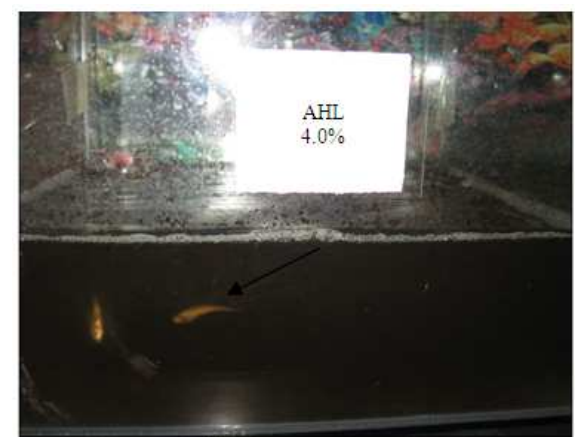

Fig. 6: The behavioural changes of carp fish Exposed to $4.0 \%$ of AHL

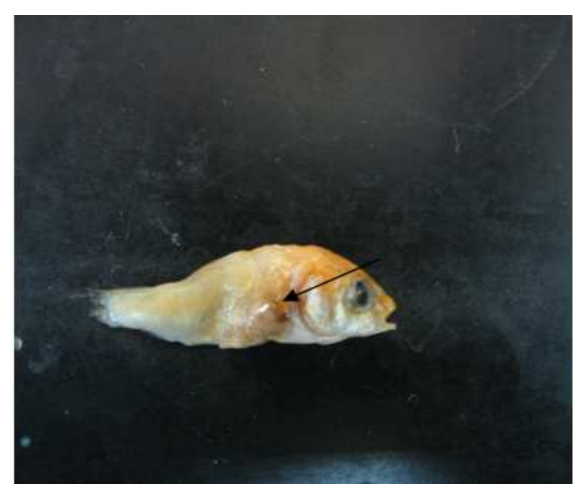

Fig. 7: Mucous secretion from carp skin

Moreover at the highest concentration 4.0, 4.6 and 7.5\% (AHL, ATL and SSL respectively), all the fish were motionlessly sank towards bottom of the flasks with noticeable increase in mucous secretions, hemorrhage in the gills and the skin color became lighter. All the fish died after 30, 42 and $78 \mathrm{~h}$ (AHL,
ATL and SSL respectively) of the tests; at these concentrations $100 \%$ mortality was recorded.

\section{DISCUSSION}

Physico-chemical characteristics of landfill leachate: Leachate composition varies significantly among landfills, depending on waste composition, waste age and landfilling technology, operation mode of a landfill, climate and hydrogeological conditions as well as those inside the landfill (biochemical activity, moisture, temperature, $\mathrm{pH})^{[19-20]}$. Generally, it is accepted that landfills undergo at least four phases of decomposition, (1) an initial aerobic phase, (2) an anaerobic acid phase, (3) an initial methanogenic phase and (4) a stable methanogenic phase ${ }^{[21-22]}$. There is a strong relationship between the state of refuse decomposition and its associated leachate characteristics. AHL was black in color and had a strong odor of ammonium, ATL was dark brown in color with a recognizable odor of ammonium and SSL was bright brown in color with slightly ammonium odor.

The $\mathrm{pH}$ value is an indicator of the aggressiveness of the leachate and aerobic versus anaerobic conditions in the refuse. The measured $\mathrm{pH}$ values were in a relatively narrow range around neutral (7.36-7.9) which is within the allowable limits. More neutral $\mathrm{pH}$ values are expected in the leachates that have already undergone some stabilization, while mature landfills display $\mathrm{pH}$ values greater than $7^{[23]}$. Conductivity is used as an indicator of the abundance of dissolved inorganic species or total concentration of cations and anions. For the leachate samples studied, the range of conductivity values was wide from 10.14 and 14.72 for SSL and ATL respectively to $26.34 \mathrm{mS} \mathrm{cm}^{-1}$ for AHL. Generally, the mean values of conductivity in all leachates were within the normal range for typical municipal landfill leachate reported in Malaysia ${ }^{[24]}$.

The highest value for DO of $2.52 \mathrm{mg} \mathrm{L}^{-1}$ was recorded for ATL whereas lower values of 1.13 and $0.78 \mathrm{mg} \mathrm{L}^{-1}$ were obtained in SSL and AHL respectively. Leachate from municipal landfill usually contain very low Dissolved Oxygen (DO) levels because of waste compression processes and also due to aerobic decomposition of the wastes in which microbes use up oxygen to transform organic materials to inorganic substances ${ }^{[25]}$. Several bulk parameters are used to describe the content of dissolved organic matter in leachate, Total Organic Carbon (TOC), Chemical Oxygen Demand (COD) and Biological Oxygen Demand (BOD). This study included the measurements 
of COD and BOD. AHL has scored the highest COD value of $7600 \mathrm{mg} \mathrm{L}^{-1}$, whereas, lower content values of 3733.3 and $1640 \mathrm{mg} \mathrm{L}^{-1}$ were obtained for ATL and SSL respectively. Similarly, the greatest BOD content value of $1228 \mathrm{mg} \mathrm{L}^{-1}$ was measured in AHL, whereas the least values of 866 and $507 \mathrm{mg} \mathrm{L}^{-1}$ were obtained for ATL and SSL respectively. These values are generally within the normal range of typical municipal landfill leachate ${ }^{[26]}$. A BOD/COD ratio greater than 0.5 indicates a young landfill, when the ratio is less than 0.1 , the landfill can be considered old and stable, whereas the ratio 0.1-0.5 indicates partially stable leachate ${ }^{[26]}$. Therefore, in a given leacates, the values of $\mathrm{BOD} / \mathrm{COD}$ ratio ranged from 0.16 to 0.3 which indicates the partial stabilization of these leachates.

Ammoniacal-nitrogen $\left(\mathrm{NH}_{3}-\mathrm{N}\right)$ is a common constituent of landfill leachate as a result of the biological degradation of amino acids and other nitrogenous organic matter. $\mathrm{NH}_{3}-\mathrm{N}$ seems to be the constituent that lasts long term in landfill leachate and may be used to determine the remaining pollution potential in the landfill and the required after-care period ${ }^{[27]}$. Concentrations of $\mathrm{NH}_{3}-\mathrm{N}$ in the three landfill leachates were $321-956 \mathrm{mg} \mathrm{L}^{-1}$. The alkalinity of the leachates was highly variable and ranged from $1580 \mathrm{mg}$ $\mathrm{L}^{-1}$ as $\mathrm{CaCO}_{3}$ at SSL to $8300 \mathrm{mg} \mathrm{L}^{-1}$ as $\mathrm{CaCO}_{3}$ at AHL. These concentrations are typical for landfill leachates in the early phases of waste stabilization ${ }^{[26]}$. The role of ammonia and alkalinity as potential toxicant in landfill leachates has been hypothesized by several authors ${ }^{\text {[28- }}$ ${ }^{29]}$. Total Dissolved Solids (TDS) fluctuated in a small range among the examined leachate. The greatest concentration content of $9780 \mathrm{mg} \mathrm{L}^{-1}$ was measured for AHL followed by 7220 and $6042 \mathrm{mg} \mathrm{L}^{-1}$ for ATL and SSL respectively. These values in turn may reflect the large content of soluble ions particularly inorganic. Khoury et al $^{[30]}$ had noticed a positive correlation between the variation of EC and TDS in the municipal landfill leachate.

Toxicity tests: Based on Finneys Probit Analysis Method using EPA software program, the mean $\mathrm{LC}_{50}$ values of landfills leachate from the three landfills (AHL, ATL and SSL) using C. carpio individuals with an average weight of $0.92 \pm 0.24 \mathrm{~g}$ and average length of $3.83 \pm 0.19 \mathrm{~cm}$ was found to be $1.132,2.0$ and $3.822 \%$ respectively. The $95 \%$ confidence limits were $(0.475-$ $1.979 \%),(1.569-2.504)$ and (2.918-4.890) respectively. Although the effects of the toxicity of landfill leachate on fish were studied in numerous fish species, it is difficult to make a direct comparison amongst the available results, since leachate toxic components concentration differ among different landfills, methods of calculating the $\mathrm{LC}_{50}$ are not same and fish size and species are different. There are no similar studies carried out to estimate the toxicity of landfill leachate using $C$. carpio as test organism.

However, the overall mean $\mathrm{LC}_{50}$ values recorded in this study for $C$. carpio were significantly different from those reported by other researcher on other fish species: Sisinno et al. ${ }^{[12]}$ evaluated acute toxicity of pure and treated dump leachate to zebrafish (Brachydanio rerio) weighing 0.2-0.4 $\mathrm{g}$ and having an average length of $2.0-3.0 \mathrm{~cm}$. The $48 \mathrm{~h} \mathrm{LC}_{50}$ values of pure leachate samples were included in a range of 2.2$5.7 \%(\mathrm{v} / \mathrm{v})$, indicating low variation between the obtained results in the different sampling. Osaki et $a l .{ }^{[13]}$ reported $48 \mathrm{~h} \mathrm{LC}_{50}$ values as $19.2 \%$ and $53.0 \%$ for adults (body length of $2.5-3.5 \mathrm{~cm}$ and weight of 0.3 g) and larvae of Japanese killifish medaka (Oryzias latipes), respectively. The $96 \mathrm{~h} \mathrm{LC}_{50}$ for leachates of two different sampling months on tilapia (Sarotherodon mossambicus) were 1.4 and $12 \%^{[11]}$.

Among the other observed results, landfill leachate is highly toxic to carp fish, AHL leachate showed the highest toxicity with a 100\% mortality caused by concentration of $4.0 \%(\mathrm{v} / \mathrm{v})$ after $30 \mathrm{~h}$, followed by ATL laechate with $4.6 \%(\mathrm{v} / \mathrm{v})$ after $42 \mathrm{~h}$ and lastly SSL leachate with $7.5 \%$ (v/v) after $78 \mathrm{~h}$. Similar result was recorded by Kaur et al. ${ }^{[31]}$, all of the leachates tested at $8 \%(\mathrm{v} / \mathrm{v})$ concentration caused $100 \%$ mortality after 24 $\mathrm{h}$ for Japanese Medaka (Oryzias latipes) embryos.

Relationship between chemical parameters and toxicity of leachate: In general, the BOD, COD and $\mathrm{NH}_{3}-\mathrm{N}$ contents for the all leachate samples exceeded the standard limits of 50,100 and $150 \mathrm{mg} \mathrm{L}^{-1}$ respectively for environmental release of effluents determined by the Malaysian Health Ministry to an extreme degree. Clement et al. ${ }^{[32]}$ stated that ammonia, heavy metals and organic compounds (such as tannins, legnin and phenol) may individually or in combination be responsible for the observed toxicity of landfill leachates. Furthermore, toxicity in the leachates from several landfills in Sweden and Lithuania have been attributed to ammonium/ammonia components and to organic pollutants ${ }^{[33]}$, similar results also were found in Brazil by Silva et al. ${ }^{[34]}$ and in Italy by Pivato and Gaspari $^{[35]}$. The 96 LC50 values of ammonia acute toxicity test on $C$. carpio fry were reported to be between 0.43 and $2.1 \mathrm{mg} \mathrm{L^{-1 }}$ by Hasan and Machintosh $^{[36]}$. In another study to evaluate the toxicity of un-ionized ammonia and ammonium on C. carpio maintained at different $\mathrm{pH}$ levels and different weights ${ }^{[37]}$, the $96 \mathrm{LC}_{50}$ values recorded were 0.87 and 
$52.2 \mathrm{mg} \mathrm{L}^{-1}$ respectively for fish weighing $5.2 \mathrm{~g}$ and on $\mathrm{pH} 7.5$.

The change in behavioral pattern: Among the behavioral changes observed for the individual fish at different leachate concentrations, decline in general activity, loss of balance, breathing difficulties, excessive mucosal secretion and gathering at the surface for breathing. Our results are in agreement with the results reported by many other researchers: Sarikaya and Yilmaz ${ }^{[38]}$ in their investigation of acute toxicity of [2, 4-D (2, 4 dichlorophenoxy) acetic acid] herbicide on the behavior of the common carp (Cyprinus carpio L.) determined their 96-h LC50 values and reported behavioral changes in fish. They also observed anxiety, swimming upside down, loss of balance, excessive mucus secretion and lightening in color, gathering at the surface for breathing and hitting to the side walls of the aquaria.

Viran et al.$^{[39]}$ reported in their study of deltamethrin acute toxicity on guppies (Poecilia reticulata), rapid gill movement, erratic swimming, swimming at the water surface and gulping for air and prolonged and motionless laying down on the aquarium bottom observed at all concentrations above $4.00 \mathrm{mg} \mathrm{L}^{-1}$. The highest concentration $\left(10.80 \mathrm{mg} \mathrm{L}^{-1}\right)$ showed all responses at high levels. Polat et al. ${ }^{[40]}$ conducted their study on acute toxicity of beta-cypermethrin using guppies Poecilia reticulate. Color change to yellow in the abdominal area, turning around its axis, gathering at one corner on the surface of the aquarium, backbone defects such as bending, enlargement of the eyes and keeping the gills in open position for prolonged periods were their observations for the highest concentration $\left(50 \mu \mathrm{g} \mathrm{L}^{-1}\right)$. Baser et al. ${ }^{[41]}$ in their investigation of acute toxicity of permethrin on Poecilia reticulate found that, the concentration of $525.0 \mu \mathrm{g} \mathrm{L}^{-1}$ showed many responses at high intensities, among them, the loss of equilibrium, hanging vertically in water, rapid gill movement, erratic swimming, sudden swimming motion in a spiral fashion. Although the previous studies used different toxic test materials, the behavioral changes that they concluded similar to the one concluded by this study.

\section{CONCLUSION}

Leachate migrates vertically and laterally into the environment by direct discharge into the adjacent streams. Toxic compounds inside leachate texture effect fish, which are the last chain of the feeding cycle in aquatic eco-system, and cause other animals and human being, which feed on fish, to be subjected to the same toxic effect.
Unfortunately, the published work on acute toxicity of landfill leachate using fish is considered rare in the open literature. This study of acute toxicity to the recommended fish species for toxicity testing, $C$. caprio, is considered the first in Malaysia. Further work with toxicity testing methods directly on fish will be very useful in assessing possible ecological risk assessment of landfill leachate.

\section{ACKNOWLEDGMENT}

The authors would like to thank the Ministry of Science Technology and Innovation for the financial support for this research. Grant no. (04-01-02-sf0418).

\section{REFERENCES}

1. El-Fadel, M., A.N. Findikakis and J.O. Leckie, 1997. Environmental impacts of solid waste landfilling. J. Environ. Manage. 50: 1-25.

Doi:10.1006/jema.1995.0131.

2. Christensen, T.H., P. Kjeldsen, P.L. Bjerg, D.L. Jensen, B.J. Christensen, A. Baum and H.G. Albrechtsen, 2001. Biogeochemistry of landfill leachate plumes. Applied Geochem., 16: 659-718. Doi: 10.1016/S0883-2927(00)00082-2.

3. Pivato, A. and L. Gaspari, 2005. Acute toxicity test of leachates from traditional and sustainable landfills using luminescent bacteria. Waste Manage., 26: 1148-1155. Doi:10.1016/j.wasman.2005.10.008.

4. Paxeus, N., 2000. Organic compounds in municipal landfill leachates. Water Sci. Technol.,42: 323-333. http://www.iwaponline.com/wst/04207/wst04207 0323.htm.

5. Schwarzbauer, J., S. Heim, S. Brinker and R. Littke, 2002. Occurrence and alteration of organic contaminants in seepage and leakage water from a waste deposit landfill. Water Res., 36: 2275-2287. Doi: 10.1016/S0043-1354(01)00452-3.

6. Bae, J.H., S.K. Kim and H.S. Chang, 1997. Treatment of landfill leachates: ammonia removal via nitrification and denitrification and further COD reduction via fenton's treatment followed by activated sludge. Water Sci. Technol., 36: 341-348. Doi: 10.1016/S0273-1223(97)00736-1.

7. Agamuthu, P., 2001. Solid wastes: Principles and Management with Malaysian Case Studies. University of Malaya Press. Kuala Lumpur. Malaysia. ISBN: 983-2085-26-8.

8. Buikema, A.L., B.R. Niederlehner and J.J. Cairns, 1982. Biological monitoring. Part IV-Toxicity testing. Water Res., 16: 239-262.

Doi: 10.1016/0043-1354(82)90188-9. 
9. Castano, A., M.J. Cantarino, P. Castillo and J.V. Tarazona, 1996. Correlation between the RTG-2 cytotoxicity test $\mathrm{EC}_{50}$ and in vivo $\mathrm{LC}_{50}$ rainbow trout bioassay. Chemosphere, 32: 2141-2157. Doi: 10.1016/0045-6535(96)00126-9.

10. Stephen, P. and M.R. Neil, 1984. Multiple bioassays to assess the toxicity of a sanitary landfill leachate. Arch. Environ. Contam. Toxicol., 13: 197-206. Doi: 10.1007/BF01055877.

11. Wong, M.H., 1989. Toxicity test of landfill leachate using Sarotherodon mossambicus (freshwater fish). Ecotoxicology and Environ. Safe., 17: 149-156.

Doi: 10.1016/0147-6513(89)90033-X.

12. Sisinno, C.L.S., E.C. Oliveira-Filho, E.M.C. Dufrayer, J.C. Moreira and F.J.R. Paumgartten, 2000. Toxicity evaluation of a municipal dump leachate using zebrafish acute tests. Bull. Environ. Contam. Toxicol., 64: 107-113. Doi: $10.1007 / \mathrm{s} 001289910017$.

13. Osaki, K., K. Shosaku, T. Norihisa and O. Yoshiro, 2006. Toxicity testing of leachate from waste landfills using Medaka (oryzias latipes) for monitoring environmental safety. Environ. Monitor. Assess., 117: 73-84. Doi: 10.1007/s10661-006-7670-x.

14. APHA., 1998. Standard Methods for the Examination of Water and Wastewater. $18^{\text {th }}$ edition, APHA, Washington, DC. ISBN: 0-87553235-7.

15. OECD., 1993. Organization for Economic CoOperation and Development. OECD Guidelines for Testing of Chemicals, Test No. 203: Fish Acute Toxicity Test, OECD, Paris, France. http://www.oecd.org/dataoecd/17/20/1948241.pdf.

16. US EPA, 1998. Ecological Effects Test Guidelines. Fish Acute Toxicity Test: Freshwater and Marine. Washington.DC.

http://www.epa.gov/opptsfrs/publications/OPPTS Harmonized/850_Ecological_Effects_Test_Guideli nes/Drafts/850-1075.pdf.

17. Kirchen, V. and R.V. West, 1976. The Japanese medaka: Its care and development. Carolina Biological Co. Burlington, North Carolina, pp: 1-36.

18. US EPA, 1999. LC $_{50}$ Software Program: Version 1.00. Center for Exposure Assessment Modeling (CEAM). Distribution Center.

19. Lema, J.M., R. Mendez and R. Blazquez, 1988. Characteristics of landfill leachates and alternatives for their treatment: A review. Water Air Soil Pollut., 40: 223-250. Doi: 10.1007/BF00163730.

20. Christensen, T.H., P. Kjeldsen, H.J. Albrechtsen, G. Heron, P.H. Nielsen, P.L. Bjerg and P.E. Holm, 1994. Attenuation of landfill leachate pollutants in aquifers. Crit. Rev. Environ. Sci. Technol., 24: 119-202. ISSN: 1064-3389.
21. Farquhar, C.J. and F.A. Rovers, 1973. Gas production during refuse decomposition. Water Air Soil Pollut. M., 2: 483-495.

Doi: 10.1007/BF00585092.

22. Christensen, T.H. and P. Kjeldsen, 1995. Landfill emissions and environmental impact: An introduction. Proceedings of the 5th International Symposium on Landfill, Cagliari, Italy. Environmental Sanitary Engineering Center. CISA. pp. 635-646.

23. Chian, E. and F.B. Dewelle, 1976. Sanitary landfill leachate and their treatment. J. Environ. Eng. Divis., 102: 411-431.

24. Agamuthu, P., 1999. Characterization of municipal solid waste leachate from selected landfills in Malaysia. Malaysian J. Sci., 18: 99-103.

25. Bagchi, A., 1994. Design, Construction and Monitoring of Landfills. $2^{\text {nd }}$ edition, John Wiley and Sons, New York., ISBN: 978-0471306818.

26. Kjeldsen, P., M.A. Barlaz, A.P. Rooker, A. Baun, A. Ledin and T.H. Christensen, 2002. Present and long-term composition of MSW landfill leachate. Crit. Rev. Environ. Sci. Technol., 32: 297-336. Doi: 10.1080/10643380290813462.

27. Kruempelbeck, I. and H.J. Ehrig, 1999. Long-term behavior of municipal solid waste landfills in Germany. Proseedings of the 7th Symposium on Waste Management and Landfill, Sardinia, Italy, October 4-7, pp: 27-36.

28. Clement, B., G. Persoone, C. Janssen and A. Le Dfi-Delepierre, 1996. Estimation of the hazard of landfills through toxicity testing of leachates: Determination of leachate toxicity with a battery of acute tests. Chemosphere, 33: 2303-2320. Doi: 10.1016/0045-6535(96)00322-0.

29. Clement, B. and G. Merlin, 1995. The contribution of ammonia and alkalinity to landfill leachate toxicity to duckweed, Sci. Total Environ., 171: 71-79. Doi: 10.1016/0048-9697(95)04563-G.

30. Khoury, R., M. El-Fadel, S. Sadek and G. Ayoub, 2000. Temporal variation of leachate quality in seawater saturated fills. Adv. Environ. Res., 4:313-323.Doi:10.1016/S1093-0191(00)00031-9.

31. Kaur, R., B. Buckley, S.S. Park, Y.K. Kim and K.R. Cooper, 1996. Toxicity test of Nanji Island landfill (Seoul, Korea) leachate using Japanese Medaka (Oryzias latipes) embryo larval assay. Bull. Environ. Contam. Toxicol., 57: 84-90. Doi: 10.1007/s001289900159.

32. Clement, B., C. Delolme, T. Winiarski and Y. Bouvet, 1993. The risk of contamination by leachates of freshwater ecosystems. Proceedings of the 4th International Symposium on Landfill, Margherita di Pula, pp: 1155-1166. 
33. Svensson, B.M., L. Mathiasson, L. Martensson and S. Bergstrom, 2005. Artemia salina as test organism for assessment of acute toxicity of leachate water from landfills. Environ. Monitor. Assess., 102: 309-321.

Doi: 10.1007/s10661-005-6029-z.

34. Silva, A.C., M. Dezotti and G.L. Sant Anna Jr., 2004. Treatment and detoxification of a sanitary landfill leachate. Chemosphere, 55: 207-214. Doi:10.1016/j.chemosphere.2003.10.013.

35. Pivato, A. and L. Gaspari, 2006. Acute toxicity test of leachates from traditional and sustainable landfills using luminescent bacteria. Waste Manage., 26: 1148-1155.

Doi:10.1016/j.wasman.2005.10.008.

36. Hasan, M.R. and D.J. Machintosh, 1986. Acute toxicity of ammonia to common carp fry. Aquaculture,54:97-107. http://cat.inist.fr/?aModele $=$ afficheN \&cpsidt $=7995$ 607

37. Hossam, H.A., 2006. Acute toxicity of ammonia to common carp fingerlings (Cyprinus carpio) at different pH levels. Pak. J. Biol. Sci., 9: 2215-2221. http://www.scialert.net/pdfs/pjbs/2006/22152221.pdf
38. Sarikaya, R. and M. Yilmaz, 2003. Investigation of acute toxicity and the effect of 2,4-D (2,4dichlorophenoxyacetic acid) herbicide on the behavior of the common carp (Cyprinus carpio L.). Chemosphere, 52: 195-201. Doi: 10.1016/S0045-6535(03)00106-1.

39. Viran, R., F. U. Erkoc, H. Polat and O. Kocak, 2003. Investigation of acute toxicity of deltamethrin on guppies (Poecilia reticulata). Ecotoxicol. Environ. Safe., 55: 82-85. Doi: 10.1016/S0147-6513(02)00096-9.

40. Polat, H., F.U. Erkoc, Viran, R. and K. Oner, 2002. Investigation of acute toxicity of beta-cypermethrin on guppies Poecilia reticulates. Chemosphere, 49: 39-44. Doi: 10.1016/S0045-6535(02)00171-6.

41. Baser, S., E. Ercok, M. Selvi and O. Kocak, 2003. Investigation of acute toxicity of permethrin on guppies Poecilia reticulates. Chemosphere, 51: 469-474. Doi: 10.1016/S0045-6535(03)00033$\mathrm{X}$. 